\title{
Editorial
}

\section{No Imagining too Radical, no Action too Disruptive}

\author{
Blythe Bell, RN, PhD (c) \& Cheryl van Daalen-Smith, RN, PhD
}

Cite As: Bell, B. \& van Daalen-Smith, C. (2021). No Imagining too Radical, no Action too Disruptive. Editorial. Witness: The Canadian Journal of Critical Nursing Discourse. Vol 3(1), pp 1-3. https://doi.org/10.25071/2291-5796.104

In the aftermath of our collective witnessing of the racism-provoked deaths of George Floyd and Joyce Echaquan, the editorial board collectively decided to dedicate this issue of Witness to critical anti-racist discourses that enact a path forward of resistance and sustained change. The explicit summons to Disrupt Nursing was (and is) an invitation to nurses and allies to engage in critical discourse about nursing's complicit role in perpetuating the structural violence of White supremacy, and to explore opportunities for the integration of anti-racist, anti-oppressive praxis to advance social justice. While nursing's commitment to anti-racism is unfolding, it remains tepid-at-best.

While this 'special' issue creates a container for a body of critical anti-racist nursing work, there is nothing 'special' about decolonizing efforts, or facilitating the critical reappraisal of governance systems that reify Whiteness in the name of regulatory cohesion. While it is our hope that this issue, among others being published this year, can act as inspiration for the development of nursing thought and action that explicitly names and addresses a White supremacist hierarchy of human value here in Canada, in nursing, and in ourselves, it is not enough. The disruption this issue calls for must be within each of us, across all of us, and enacted substantively by the profession in its' entirety.

As we moved towards the final production of this current issue of Witness, Canada, as a country, was viscerally reminded of the imperialist genocide of Indigenous children through structural racism within which nursing and other professions are implicated. Canada's Sally Thorne (2019), in the wake of the release of the National Inquiry into Missing and Murdered Indigenous Women and Girls (NIMMIWG, 2019) report, called out Canada and Canadian nursing for our complicity in what the report described as a genocide and which Thorne named a "genocide by a million papercuts." When Thorne unapologetically asked "and what of nurses in all of this?", she confronted the relative ease of nurses to distance ourselves from the very thought that we would ever have participated. Indeed, the photos of residential school nurses or the multiple images of staircases laden with 215 pairs of indictmentserving tiny shoes, beg to differ.

The tentativeness in the use of the word genocide is over. The question is no longer should or when. The question before us is how. How will nursing resist and disrupt hegemonic discourses that fuel such atrocities? How will nursing confront "the sum of the social practices, assumptions, and actions" (NIMMIWG, 2019, p. 3 ) that give way to policies and practices which reify hierachies of human value?

The hero and angel narrative that often draws young people into the profession has been well critiqued as an unconscious mask that impedes authentic reflexivity about individual and systemic complicity with colonialism and systemic racism (Smith \& Foth, 2021; Symenuk et al., 2020). This default narrative has been amplified tenfold this past year as the public and 
the media have taken the opportunity to reflect on the reality and risks of nursing work, albeit through a narrow and mediated lens. Pierre Bourdieu's social analysis identifies doxa, or rules of engagement, established by the top of a hierarchy, which are followed by all who strive for such a position of power (Bourdieu \& Wacquant, 2013). While nursing, as a profession, continues to spar for social position and a seat at various tables of influence, a critical question remains: What doxa is central within nursing that encumbers fundamental change? Is it the doxa of (White) nursing innocence?

Ruby Hamad (2019) ties the notion of innocence, often associated with nursing's perennial angel narrative, directly to the maintenance of a racial order that is enacted by those embodying an imperialist European feminity: privileged White women, such as ourselves as two White nursing academics. Hamad (2019) argues that the 'White woman as innocent' narrative is the cornerstone of White supremacy that permits violence against Others. Those of us in the White woman structural position therefore have a responsibility to challenge and reject this narrative, this doxa, designed to oppress specifically for our benefit. For as long as we use the Master's tools, first referred to by Audre Lorde (1984), we can never dismantle the racial underpinnings of the myth of innocence. "In Bourdieusian terms, then, the tools are the doxa and the house the social field. One may find success in abiding by the masters's doxa, but one will never become the master, nor will one ever by free" (Bell, 2020, p. $5)$.

An authentic consideration of disciplinary decolonization would consider abolition as an imperative. In so doing, we would move forward asking, "what of nursing needs to be abolished?", where abolition "is fundamentally about imagining a different way of addressing the structural determinants of harm. We must learn abolition as a nursing intervention" (Paynter et al., 2020, p. 471), not only to redress societal harms on the people we care for, but also for the integrity of the nursing role. For example, those of us on, or eyeing, the ladder in academia or nursing leadership would be called forth to consider which comforts or exclusions we seek by participating in these colonial structures, and the impact of the gained privileges on others around us. We could consider whether the security of such positions, and tenets such as academic freedom, are being applied towards justice and equity, or in deflection of responsibility. Another consideration would be to critically interrogate who and what our self-regulatory functions are protecting; and, if our governance systems are not protecting all patients, all students, and all nurses from harm, then let us perhaps start there. And finally, as many critical nurse scholars continue to do, we must interrogate whether our accredited educational programs are consistently producing thoroughly anti-oppressive nurses. With so many questions in front of us, there is no shortage of work to be done. Can our accreditation and regulation processes be consdidered valid if they do not explicitly and exhaustedly establish and maintain accountability procedures for all measures of harm? If not, we must resoundedly ask, "who then, are they serving?"

On June $9^{\text {th }}, 2021$, with input from the Canadian Indigenous Nurses Assocation, the Canadian Nurses Association, the Canadian Federation of Nurses Unions, the Canadian Nursing Students Associations, and the Nurse Practitioner Association of Canada, released a Nursing Declaration Against Anti-Indigenous Racism in Nursing and Health Care (CNA, 2021). Its intentional declarative ethos identifies actions by which individual nurses, nursing organizations, and the nursing profession at large will be held to account. A follow-up national summit on Racism in Nursing and Health Care in Canada is planned with the central thrust being discussions regarding progress. What will progress look like and how will we measure it?

If you stick a knife in my back 9 inches and pull it out 6 inches, there's no progress. If you pull it all the way out, that's not progress. The progress is healing the wound that the blow made and they haven't pulled the knife out ... they won't even admit that it's there.

(Malcolm X, 1964/Imagine Justice, n.d.) 
Malcolm X's metaphor provides an apt method to assess anti-racist and de-colonizing engagement in nurses and nursing institutions alike. In dialogue for this piece, we (Blythe and Cheryl) asked ourselves the following questions in order to self-locate on Malcolm X's continuum of anti-racist progress, and we invite our cherished readers to consider the salience of such a reflection for themselves:

When I consider the work I am doing in my mind, in my scholarship, my teaching, my practice, and within my social circles, where do I live along this continuum of anti-racist and reconciliatory progress? Am I satisfied to ease the knife back 3 inches? Do I see the knife but do nothing about it? Am I committed to changing myself and the environments I inhabit significantly enough in both thought and practice that the knife comes out and the wound heals? Where along this continuum of engagement am I directing my energies, and what does this tell of my understanding of the level of harm racialized and marginalized people have experienced and continue to experience in Canada, and in Canadian nursing specifically? And what does it tell of my complicity in normalizing or perpetuating only incremental change?

There can be no imagining too radical, nor action too disruptive, when correcting course towards anti-racism, justice, and equity. Who and what is being privileged by tepid, tentative, and time-limited efforts? What is behind the incremental change we are witnessing? Is it fear? Is it nostalgia? Is it White supremacy sustaining itself? What are we protecting, if not everybody, if not every body?

\section{Declaration of Conflicting Interests}

The authors declared no potential conflicts of interest with respect to the authorship and publication of this article.

\section{Funding}

The authors received no financial support for the authorship and publication of this article.

\section{References}

Bell, B. (2020). Towards abandoning the master's tools: The politics of a universal nursing identity. Nursing Inquiry, 28(2), 112. https://doi.org/10.1111/nin.12395
Bourdieu, P., \& Wacquant, L. (2013). Symbolic capital and social classes. Journal of Classical Sociology, 13(2), 292-302. https://doi.org/10.1177/1468795X12468736

CNA. (2021). Nursing declaration against antiIndigenous racism in nursing and health care. Retrieved June $9^{\text {th }}, 2021$ from: https://cna-aiic.ca/-/media/cna/pagecontent/pdf-en/1 0876-nursing-declarationagainst-anti-indigenous-racism-in-nursingand-health-care-en-v3-

copy.pdf?la=en\&hash=21C8126F07F9BF11 F4E2DD729AE34258A2AB0EBE

Hamad, R. (2019). White tears/brown scars: How white feminism betrays women of color. Catapult.

Lorde, A. (1984). Sister outsider: Essays and speeches. Crossing Press.

National Inquiry into Missing and Murdered Indigenous Women and Girls. (2019). Reclaiming power and place: Executive summary of the final report. Retrieved from https://www.mmiwg-ffada.ca/final-report/

Paynter, M., Jefferies, K., \& Carrier, L. (2020). Nurses for police and prison abolition/ Infirmières pour l'abolition de la police et des prisons/Enferemeras para la abolición de la policia y las prisones. Public Health Nursing, 37(4), 471-474. https://doi.org/10.1111/phn.12766

Shabazz, M. [MalcomShabazz]. (2018, February 13). Malcolm X: If you stick knife in my back nine inches... [video]. Youtube.

https://www.youtube.com/watch?v=DlfjmZw $\underline{72 \mathrm{bo}}$

Smith, K., \& Foth, T. (2021). Tomorrow is cancelled: Rethinking nursing resistance as insurrection. Aporia, 13(1), 15-25. https://doi.org/10.18192/aporia.v13i1.5263

Symenuk, P., Tisdale, D., Bourque-Bearskin, D., \& Munro, T. (2020). In search of the truth: Uncovering nursing's involvement in colonial harms and assimilative policies five years post Truth and Reconciliation Commission. Witness: The Canadian Journal of Critical Nursing Discourse, 2(1), 84-96. https://doi.org/10.25071/2291-5796.51

Thorne, S. (2019). Genocide by a million paper cuts. Nursing Inquiry, 1-3. https://doi.org/10.1111/nin.12314 